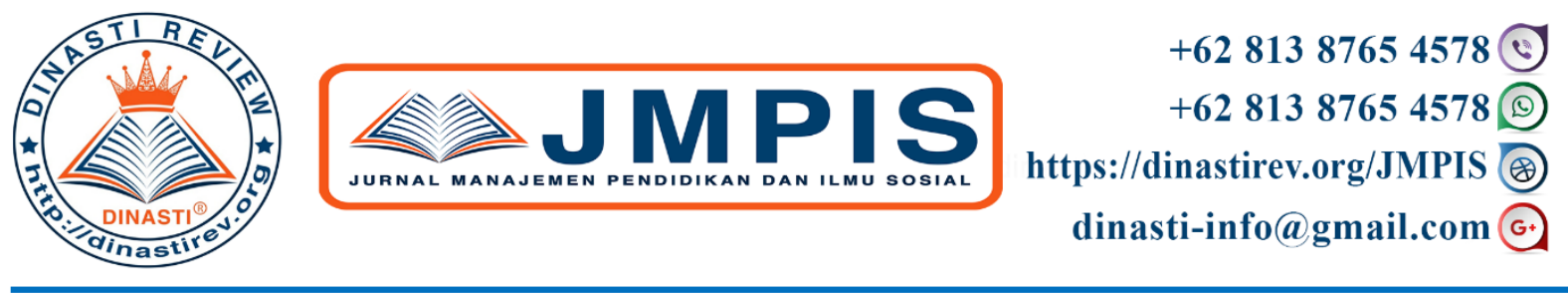

\title{
ANALISIS SWOT DALAM MENENTUKAN STRATEGI PENGEMBANGAN BANDAR UDARA INANWATAN YANG MEMENUHI STANDAR KEAMANAN DAN KESELAMATAN PENERBANGAN DAN MEMBERI DAMPAK PERTUMBUHAN EKONOMI BAGI MASYARAKAT INANWATAN
}

\section{Taufik Rahman ${ }^{1)}$}

${ }^{1)}$ Universitas Terbuka, UPBJJ - Universitas Terbuka Sorong

ARTICLE INFORMATION

Received: 11 Mei 2020

Revised: 18 Mei 2020

Issued: 28 Mei 2020

Corresponding author: first author E-mail: taufikrahman.lanjuts2ut@gmail.com

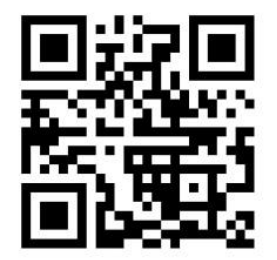

DOI:10.38035/JMPIS
Abstrak: Kantor Unit Penyelenggara Bandar Udara (UPBU) Inanwatan, Kabupaten Sorong Selatan adalah unit pelaksana di lingkungan Direktorat Jenderal Perhubungan Udara yang berada di bawah dan bertanggung jawab langsung kepada Direktur Jenderal Perhubungan Udara. Di dalam memberikan pelayanan kepada pengguna jasa transportasi udara, Kantor UPBU Inanwatan melayani angkutan udara perintis dengan rute Sorong - Inanwatan - Teminabuan - Inanwatan - Sorong. Kantor UPBU Inanwatan di samping berkewajiban memenuhi standar-standar keamanan dan keselamatan penerbangan, pelayanan angkutan udara perintis yang diberikan juga harus memberikan dampak pertumbuhan ekonomi bagi masyarakat Inanwatan. Letak geografis Kecamatan Inanwatan yang berada di daerah pesisir membuat mata pencaharian utama dari penduduk di Kecamatan Inanwatan adalah nelayan. Hanya sebagian kecil penduduk yang bekerja di bidang pertanian dan peternakan dan juga Pegawai Negeri Sipil. Di dalam data Badan Pusat Statistik Kabupaten Sorong Selatan Tahun 2019 tidak disebutkan pendapatan perkapita penduduk Inanwatan, namun dilihat dari mata pencaharian penduduk yang bergantung dari hasil laut yang tidak menentu, dapat disimpulkan bahwa penduduk Inanwatan rata-rata hidup di bawah garis kemiskinan. Analisis SWOT dipilih untuk mengevaluasi kekuatan (strength) dan kelemahan (weakness), peluang (opportunities), dan ancaman (threats) sehingga dihasilkan suatu strategi pengembangan Bandar Udara Inanwatan yang memenuhi standar keamanan dan keselamatan penerbangan dan memberi dampak pertumbuhan ekonomi bagi masyarakat Inanwatan. Strategi pengembangan Bandar Udara Inanwatan ini dilakukan secara simultan, melalui pembagian tugas sesuai tugas pokok dan fungsi yang ada di Kantor UPBU Inanwatan dengan melibatkan para pihak yang terkait, utamanya masyarakat Inanwatan.

Kata Kunci: analisis SWOT, strategi pengembangan, keamanan dan keselamatan penerbangan, pertumbuhan ekonomi

\section{PENDAHULUAN}

Distrik Inanwatan merupakan salah satu kota kecamatan yang terletak di Kabupaten Sorong Selatan, terdiri dari 9 kampung, berada di wilayah pesisir dan terletak pada satu hamparan, kecuali Kampung Isogo dan Odeari. 
Kampung-kampung di Distrik Inanwatan adalah sebagai berikut :

1. Kampung Mate;

2. Kampung Wadoi;

3. Kampung Sibae;

4. Kampung Isogo;

5. Kampung Serkos;

6. Kampung Solta Baru;

7. Kampung Mogibi;

8. Kampung Odeari; dan

9. Kampung Siri Siri.

Adapun batas-batas wilayah Distrik Inanwatan sebagai berikut :

1. sebelah utara berbatasan dengan Kecamatan Kokoda Utara;

2. sebelah selatan berbatasan dengan Kabupaten Fak-Fak;

3. sebelah barat berbatasan dengan Kecamatan Matemani; dan

4. seberah timur berbatasan dengan Kabupaten Teluk Bintuni.

Distrik Inanwatan memiliki luas wilayah $960.540 \mathrm{~km} 2$ dengan jumlah penduduk pada tahun sebanyak 3.566 jiwa (Sumber : Kecamatan Inanwatan dalam Angka 2019, Badan Pusat Statistik Kabupaten Sorong Selatan).

Letak geografis Kecamatan Inanwatan yang berada di daerah pesisir membuat mata pencaharian utama dari penduduk di Kecamatan Inanwatan adalah nelayan. Hanya sebagian kecil penduduk yang bekerja di bidang pertanian dan peternakan dan juga Pegawai Negeri Sipil.

Di dalam data Badan Pusat Statistik Kabupaten Sorong Selatan tidak disebutkan terkait pendapatan perkapita penduduk Inanwatan, namun dilihat dari mata pencaharian penduduk yang bergantung dari hasil laut yang tidak menentu, dapat disimpulkan bahwa penduduk Inanwatan rata-rata hidup di bawah garis kemiskinan.

Distrik Inanwatan masih termasuk daerah yang terpencil. Akses menuju Distrik Inanwatan hanya bisa ditempuh menggunakan transportasi laut dan transportasi udara melalui angkutan udara perintis yang disubsidi oleh Pemerintah, dengan rute Sorong - Inanwatan Teminabuan - Inanwatan - Sorong. Dalam hal melayani angkutan udara perintis tersebutlah Kantor UPBU Inanwatan berperan sebagai bandar udara di Distrik Inanwatan.

Kantor UPBU Inanwatan berada di distrik Inanwatan, kabupaten Sorong Selatan, provinsi Papua Barat dengan koordinat geografis $2^{\circ} 7^{\prime} 36.29^{\prime \prime}$ Lintang Selatan dan 132 29' 47.27" Bujur Timur.

Dalam hal penggunaan bandar udara, Bandar Udara Inanwatan termasuk dalam kriteria Bandar Udara Domestik.

Dalam hal hierarki bandar udara, Bandar Udara Inanwatan termasuk dalam kriteria Bandar Udara Pengumpan (Spoke) bagi Bandar Udara Domine Eduard Osok, Sorong yang masuk dalam kriteria Bandar Udara Pengumpul ( $\mathrm{Hub}$ ).

Menurut jenisnya, landas pacu yang dimiliki Bandar Udara Inanwatan termasuk dalam kategori Non Instrument Runway.

Berdasarkan karekteristik bandar udara yang dihubungkan dengan jenis pesawat udara terbesar yang beroperasi di bandar udara tersebut, maka kode referensi Bandar Udara Inanwatan adalah 1B.

Dalam hal sumber daya manusia, pada saat ini Kantor UPBU Inanwatan memiliki 10 orang PNS dan 21 orang outsourcing, sebesar 71,43\% dari outsourcing tersebut diambil dari suku asli di Papua Barat (Sumber: Laporan Tahunan Kantor UPBU Inanwatan Tahun 2019).

Dalam hal fasilitas bandar udara, pada saat ini Kantor UPBU Inanwatan memiliki prasarana sisi udara berupa landas pacu (runway) dengan dimensi $720 \mathrm{~m}$ x $23 \mathrm{~m}$, landas parkir (apron) dengan dimensi $60 \mathrm{~m}$ x $40 \mathrm{~m}$ tanpa memiliki landas hubung (taxiway). Untuk prasarana sisi darat, Kantor UPBU Inanwatan memiliki gedung terminal dengan luas $120 \mathrm{~m} 2$. 
Dalam hal tipe lalu lintas penerbangan yang diijinkan, pilot menerbangkan pesawat menuju Inanwatan dengan mengikuti tanda-tanda visual yang disebut VFR (Visual Flight Rules). Cara seperti ini memiliki keterbatasan, yaitu keadaan cuaca dan jarak pandang harus cukup bagus. Kecepatan pesawat yang relatif tinggi mengharuskan jarak pandang yang cukup jauh. Keadaan seperti hujan dan kabut dapat mengakibatkan jarak pandang yang berkurang. Untuk terbang dalam kondisi visual, keadaan cuaca harus cukup baik dan mempunyai jarak pandang minimum $5 \mathrm{~km}$, untuk terbang di bawah 10.000 feet.

Pada saat ini, pesawat yang beroperasi di Bandar Udara Inanwatan adalah jenis Cessna Caravan C 208 milik Susi Air. Dari spesifikasi teknis pesawat ini, panjang minimum landas pacu yang digunakan oleh pesawat pada saat mendarat adalah 2.625 feet $=800,1 \mathrm{~m}$, dimana kondisi landas pacu adalah Mean Sea Level (MSL), pada kondisi atmosfir standar, runway-nya tidak mempunyai kelandaian (Zero Runway Slope), serta tidak ada angin.

Dengan kondisi panjang runway hanya $720 \mathrm{~m}$, pesawat Cessna Caravan C 208 yang akan terbang ke Inanwatan atau lepas landas dari Bandar Udara Inanwatan harus mengurangi MTOW (Maximum Take-off Weight)-nya.

Pada saat dilakukan audit Penerbitan Register Bandar Udara Inanwatan yang dilaksanakan oleh Direktorat Bandar Udara dari tanggal 12 sampai dengan 16 Nopember 2017 terdapat temuan sebagai berikut :

1. area sisi udara belum sepenuhnya dipagar;

2. terdapat obstacle berupa bangunan sekolah dan tiang antenna radio (tinggi $\pm 30 \mathrm{~m}$ ) pada kawasan ancangan pendaratan dan lepas landas (approach) runway 26, pada sisi sebelah timur Bandar Udara Inanwatan;

3. terdapat kondisi runway strip dengan dimensi belum memenuhi ketentuan code 1 non instrument, dimana kondisi existing adalah panjang di strip beginning runway 26 adalah 23 $\mathrm{m}$ (seharusnya $30 \mathrm{~m}$ ).

Walaupun tindak lanjut terhadap temuan tersebut baru berupa tindakan pemulihan serta membuat dokumen pengelolaan keselamatan (safety plan) yang kemudian diajukan untuk mendapatkan pengecualian (exemption), namun tetaplah harus diupayakan pengembangan Bandar Udara Inanwatan yang memenuhi standar keselamatan penerbangan.

Dalam kajian studi Rencana Induk Bandar Udara Inanwatan, target akhir pengembangan Bandar Udara Inanwatan adalah dengan panjang landas pacu $1.400 \mathrm{~m}$ yang dilaksanakan secara bertahap bergantung pada jumlah permintaan penumpang dan ketersediaan anggaran negara. Namun dengan keterbatasan anggaran negara dan jumlah permintaan penumpang yang belum bisa dipenuhi dalam waktu dekat, di samping sangat pentingnya memenuhi standar keselamatan penerbangan, membuat strategi pengembangan Bandar Udara Inanwatan memerlukan adanya penyesuaian.

Sebagai target awal dalam memenuhi panjang runway minimal untuk didarati pesawat Cessna Caravan C 208 adalah memprogramkan perpanjangan runway menjadi $980 \mathrm{~m}$ x 23 m.

\section{KAJIAN PUSTAKA}

Sebelum dikemukakan mengenai strategi pengembangan Bandar Udara Inanwatan yang memenuhi standar keselamatan penerbangan, perlu dijelaskan pengertian-pengertian / istilahistilah dalam tulisan ini.

\section{Bandar Udara}

Bandar Udara adalah kawasan di daratan dan/atau perairan dengan batas-batas tertentu yang digunakan sebagai tempat pesawat udara mendarat dan lepas landas, naik turun penumpang, bongkar muat barang, dan tempat perpindahan intra dan antarmoda transportasi, yang dilengkapi dengan fasilitas keselamatan dan keamanan penerbangan, serta fasilitas pokok dan fasilitas penunjang lainnya. 
Sesuai dengan Peraturan Menteri Perhubungan nomor : PM 39 Tahun 2019 tentang Tatanan Kebandarudaraan Nasional, bandar udara memiliki peran sebagai :

1. simpul dalam jaringan transportasi sesuai dengan hierarkinya;

2. pintu gerbang kegiatan perekonomian;

3. tempat kegiatan alih moda transportasi;

4. pendorong dan penunjang kegiatan industri dan/atau perdagangan;

5. pembuka isolasi daerah, pengembangan daerah perbatasan, dan penanganan bencana; dan

6. prasarana memperkukuh wawasan nusantara dan kedaulatan negara.

Berdasarkan penggunaannya, bandar Udara dapat dibedakan menjadi :

1. Bandar Udara Internasional; dan

2. Bandar Udara Domestik.

Berdasarkan hierarkinya, bandar Udara dapat dibedakan menjadi :

1. Bandar Udara Pengumpul $(H u b)$; dan

2. Bandar Udara Pengumpan (Spoke).

Bagian-bagian dari bandar udara terdiri dari area sisi udara (air side) dan area sisi darat (land side).

Area sisi udara merupakan bagian dari bandar udara yang berhubungan dengan kegiatan lepas landas (take off) maupun pendaratan (landing). Bagian dari area sisi udara antara lain :

1. Runway adalah daerah persegi yang telah ditentukan di bandar udara untuk pendaratan atau lepas landas pesawat udara.

Runway memiliki karakteristik sebagai berikut :

a. struktur perkerasan, untuk menahan beban pesawat;

b. threshold adalah bagian awal dari runway yang bisa digunakan untuk pendaratan.

c. bahu landas pacu (shoulder), adalah daerah berbatasan dengan ujung perkerasan yang dibuat sedemikian rupa untuk memberikan transisi dari perkerasan ke permukaan di sebelahnya.

d. stopway adalah bidang persegi yang telah ditentukan di darat pada ujung jalur lepas landas yang dibuat sebagai daerah yang sesuai dimana sebuah pesawat udara bisa berhenti ketika memutuskan untuk membatalkan lepas landasnya.

e. Runway End Safety Area (RESA) adalah sebuah daerah simetris di perpanjangan sumbu runway dan menyambung dengan akhir dari jalur primer diperuntukkan untuk mengurangi resiko kerusakan pada pesawat yang terlalu dini masuk atau melewati runway.

f. Runway Strip adalah sebuah daerah yang telah ditentukan, termasuk runway dan stopway, jika ada, dengan tujuan untuk

1) mengurangi resiko kerusakan pada pesawat udara yang melewati batas runway; dan

2) melindungi pesawat udara yang terbang di atasnya ketika melakukan lepas landas atau pendaratan.

g. Clearway adalah bidang persegi yang telah ditentukan di daratan atau permukaan air yang berada di bawah kendali pihak penyelenggara, yang ditentukan atau dipersiapkan dimana sebuah pesawat udara dapat melakukan initial climb untuk mencapai ketinggian tertentu.

Adapun jenis runway menurut prosedur pendekatannya dibedakan menjadi :

a. Instrument Runway adalah salah satu jenis runway berikut ini diperuntukkan untuk operasional pesawat udara yang menggunakan prosedur pendekatan instrumen;

b. Non-instrument Runway adalah runway yang diperuntukkan untuk operasional pesawat udara menggunakan prosedur pendekatan visual atau prosedur pendekatan instrumen 
hingga pada sebuah titik dimana pendekatan bisa dilanjutkan dengan menggunakan kondisi meteorologis visual.

2. Taxiway adalah jalur tertentu pada bandar udara di darat yang ditujukan untuk pesawat udara melakukan taxi dan ditunjukan untuk menjadi penghubung antara satu bagian bandar udara dengan lainnya, termasuk antara lain:

a. aircraft stand taxilane adalah bagian dari apron dirancang sebagai taxiway dan diperuntukkan untuk memberikan akses hanya ke pesawat udara yang sedang berhenti.

b. apron taxiway adalah bagian dari sistem taxiway terletak di apron dan diperuntukkan untuk memberikan rute taxi melintasi apron.

c. rapid exit taxiway adalah taxiway terhubung dengan runway pada sebuah sudut lancip dan dirancang untuk memungkinkan pesawat udara yang mendarat untuk berbelok pada kecepatan yang lebih tinggi dibandingkan dengan jalan keluar taxiway lainnya dan karenanya bisa meminimalkan waktu penggunaan runway.

3. Apron adalah suatu area yang telah ditentukan di sebuah bandar udara yang diperuntukkan untuk mengakomodasi pesawat udara dalam menaikkan atau menurunkan penumpang, pos atau kargo, parkir atau pemeliharaan minor pesawat udara.

Area sisi darat merupakan bagian dari bandar udara yang merupakan sisi luar bangunan terminal, terbuka untuk umum (public area) dan di dalam bangunan terminal yang terbatas untuk umum (restricted public area). Bagian dari area sisi darat contohnya :

1. terminal penumpang sampai batas check-in area;

2. curb, merupakan area dimana penumpang naik turun dari kendaraan untuk menuju atau meninggalkan terminal bandara;

3. tempat parkir kendaraan.

Ada lagi objek yang karena lokasinya berbahaya bagi pergerakan pesawat udara, yaitu obstacle yang didefinisikan sebagai semua benda baik terpasang (sementara atau permanen) atau bergerak, atau bagian dari benda tersebut, yang :

1. terdapat di daerah yang diperuntukkan untuk pergerakan permukaan pesawat udara; atau

2. berada di atas permukaan yang diperuntukkan untuk melindungi pesawat udara dalam penerbangan; atau

3. berada di luar dari permukaan yang ditentukan dan telah dinilai sebagai sebuah bahaya bagi navigasi udara.

\section{Kode Referensi Bandar Udara}

Maksud dari kode referensi adalah untuk menyediakan metode sederhana dalam menghubungkan berbagai spesifikasi mengenai karakteristik bandar udara sehingga menyediakan serangkaian fasilitas bandar udara yang cocok untuk pesawat udara yang beroperasi di bandar udara tersebut.

Kapasitas pelayanan merupakan kemampuan bandar udara untuk melayani jenis pesawat udara terbesar dan jumlah penumpang/barang, diwujudkan dalam kode referensi bandar udara yang meliputi :

1. kode angka (code number) yaitu penentuan code number berkaitan dengan nilai aeroplane reference field length (ARFL) tertinggi dari pesawat udara yang akan dilayani;

2. kode huruf (code letter) yaitu penentuan code letter yang sesuai dengan wing span terpanjang dan lebar/jarak roda terluar pesawat di antara pesawat udara digunakan untuk fasilitas tersebut.

Berikut ini adalah tabel kriteria klasifikasi bandar udara : 
Tabel 1. Kode Referensi Bandar Udara

\begin{tabular}{|c|c|c|c|}
\hline & Code Element 1 & & Code Element 2 \\
\hline $\begin{array}{c}\text { code } \\
\text { number }\end{array}$ & Aeroplane reference field length & $\begin{array}{l}\text { code } \\
\text { letter }\end{array}$ & Bentang sayap \\
\hline 1 & Kurang dari $800 \mathrm{~m}$ & $\mathrm{~A}$ & Hingga tapi tidak sampai $15 \mathrm{~m}$ \\
\hline 2 & $\begin{array}{c}800 \mathrm{~m} \text { dan lebih tapi tidak sampai } \\
1.200 \mathrm{~m}\end{array}$ & B & $\begin{array}{l}15 \mathrm{~m} \text { dan lebih tapi tidak sampai } 24 \\
\mathrm{~m}\end{array}$ \\
\hline 3 & $\begin{array}{l}1200 \mathrm{~m} \text { dan lebih tapi tidak } \\
\text { sampai } 1.800 \mathrm{~m}\end{array}$ & $\mathrm{C}$ & $\begin{array}{c}24 \mathrm{~m} \text { dan lebih tapi tidak sampai } 36 \\
\mathrm{~m}\end{array}$ \\
\hline \multirow[t]{3}{*}{4} & $1.800 \mathrm{~m}$ dan lebih & $\mathrm{D}$ & $\begin{array}{c}36 \mathrm{~m} \text { dan lebih tapi tidak sampai } 52 \\
\mathrm{~m}\end{array}$ \\
\hline & & $\mathrm{E}$ & $\begin{array}{c}52 \mathrm{~m} \text { dan lebih tapi tidak sampai } 65 \\
\mathrm{~m}\end{array}$ \\
\hline & & $\mathrm{F}$ & $\begin{array}{c}65 \mathrm{~m} \text { dan lebih tapi tidak sampai } 80 \\
\mathrm{~m}\end{array}$ \\
\hline
\end{tabular}

\section{Program Keamanan Bandar Udara}

Program Keamanan Bandar Udara (Airport Security Programme) adalah dokumen tertulis yang memuat prosedur dan langkah-langkah serta persyaratan yang wajib dilaksanakan oleh Unit Penyelenggara Bandar Udara dan Badan Usaha Bandar Udara untuk memenuhi ketentuan yang terkait dengan operasi penerbangan di Indonesia.

\section{Program Pengelolaan Keselamatan}

Program Pengelolaan Keselamatan (Safety Plan) adalah daftar langkah-langkah mitigasi yang merupakan tindakan untuk menghilangkan potensi bahaya atau mengurangi probabilitas atau tingkat keparahan, sehingga dapat menurunkan kriteria dari suatu risiko dalam matrik toleransi akibat dari tidak terpenuhinya suatu persyaratan keselamatan penerbangan.

\section{Angkutan Udara Perintis}

Angkutan Udara Perintis adalah kegiatan angkutan udara niaga dalam negeri yang melayani jaringan dan rute penerbangan untuk menghubungkan daerah terpencil dan tertinggal atau daerah yang belum terlayani oleh moda transportasi lain dan secara komersial belum menguntungkan.

Adapun Rute Perintis adalah rute yang menghubungkan daerah terpencil dan daerah tertinggal atau daerah yang belum terlayani oleh moda transportasi lain dan secara komersial belum menguntungkan.

Kegiatan Angkutan Udara Perintis terdiri dari :

1. Angkutan Udara Perintis Penumpang;

2. Angkutan Udara Perintis Kargo.

Rute perintis ditetapkan dengan mempertimbangkan kriteria fungsi keperintisan, yaitu :

1. untuk menghubungkan daerah terpencil dan daerah tertinggal atau daerah yang belum terlayani oleh moda transportasi lain, dan secara komersial belum menguntungkan; dan/atau

2. untuk mendorong pertumbuhan dan pengembangan wilayah; dan/atau

3. untuk mewujudkan stabilitas pertahanan dan keamanan negara.

Kriteria daerah terpencil dan daerah tertinggal atau daerah yang belum terlayani oleh moda transportasi lain dan secara komersial belum menguntungkan meliputi: 
1. daerah yang jauh dari ibu kota propinsi dan atau tidak tersedia moda transportasi lain selain moda transportasi udara;

2. pelayanan dan ketersediaan moda transportasi selain angkutan udara tidak teratur, sulitnya aksesibilitas dan/atau

3. aktivitas kegiatan ekonomi dan pemerintahan antar daerah relatif kecil serta rendahnya hubungan sosial dan budaya antar daerah.

Kriteria mendorong pertumbuhan dan pengembangan wilayah meliputi :

1. daerah tersebut mempunyai potensi unggulan untuk dikembangkan dan adanya hubungan saling ketergantungan antar daerah dari aspek sosial, ekonomi, budaya dan pemerintahan; dan/atau

2. program pengembangan dan pembangunan antar daerah atau wilayah yang terpadu; dan/atau

3. memberi nilai tambah daerah dari aspek sosial, ekonomi dan budaya; dan/atau

4. sebagai sarana distribusi logistik untuk menunjang pemenuhan kebutuhan yang meliputi sandang, pangan, papan, pendidikan dan kesehatan.

Kriteria mewujudkan stabilitas pertahanan dan keamanan negara memenuhi kriteria sebagai berikut :

1. kedudukan daerah tersebut berdekatan dengan perbatasan negara lain; dan/ atau

2. dalam rangka mengurangi kesenjangan sosial dan ekonomi dibandingkan dengan daerah lain.

Pelaksanaan angkutan perintis dilakukan oleh badan usaha angkutan udara niaga melalui proses pelelangan sesuai peraturan perundang-undangan yang berlaku dan sesuai kesepakatan yang dituangkan dalam kontrak.

Untuk melakukan kegiatan angkutan udara perintis, badan usaha angkutan udara niaga dan pemegang izin kegiatan angkutan udara bukan niaga harus memenuhi persyaratan :

1. memiliki izin usaha angkutan udara niaga atau izin usaha angkutan udara bukan niaga yang diterbitkan oleh Direktur Jenderal yang masih berlaku;

2. memiliki Air Operator's Certificate (AOC) atau Operator's Certificate (OC) yang masih berlaku;

3. tidak dalam pengawasan pengadilan, tidak bangkrut, kegiatan usahanya tidak sedang dihentikan, dan/atau tidak sedang menjalani sanksi pidana;

4. memiliki pesawat udara paling sedikit 1 (satu) unit dan pesawat cadangan yang laik udara atau serviceable untuk mendukung operasional penerbangan perintis dengan spesifikasi pesawat udara yang sesuai dengan aspek teknis operasi keselamatan penerbangan sesuai bandara asal dan tujuan, dengan kapasitas dibawah atau sama dengan 30 (tiga puluh) tempat duduk atau maksimum berat tinggal landas 5.700 (lima ribu tujuh ratus) kilogram untuk angkutan barang.

5. dalam keadaan tertentu badan usaha angkutan udara niaga dapat mengoperasikan pesawat udara sampai dengan 50 (lima puluh) tempat duduk atau maksimum berat tinggal landas 20.820 (dua puluh ribu delapan ratus dua puluh) kilogram untuk angkutan barang, apabila:

a. tidak tersedia tipe pesawat dengan kapasitas kurang dari atau sama dengan 30 (tiga puluh) tempat duduk atau maksimum berat tinggal landas 5.700 (lima ribu tujuh ratus) kilogram pada rute perintis tersebut;

b. potensi permintaan angkutan udara cukup tinggi; dan

c. kapasitas bandar udara dapat menampung pesawat sampai dengan 50 (lima puluh) tempat duduk atau berat tinggal landas 20.820 (dua puluh ribu delapan ratus dua puluh) kilogram. 
Evaluasi pelaksanaan angkutan udara perintis dilakukan sekurang-kurangnya 1 (satu) tahun sekali oleh Direktur Jenderal Perhubungan Udara, Kantor Otoritas Bandar Udara, Kuasa Pengguna Anggaran dan/atau Unit Pelaksana Bandar Udara dan Pemerintah Daerah.

Evaluasi pelaksanaan angkutan udara perintis dilaksanakan berdasarkan :

1. fungsi keperintisan;

2. kinerja penyelenggaraan angkutan udara perintis;

3. pelaporan kegiatan angkutan udara perintis yang dilakukan secara berkala setiap bulan yang dapat dilakukan secara manual atau elektronik;

Hasil evaluasi merupakan dasar untuk :

1. penetapan sebagai rute perintis pada tahun berikutnya; atau

2. perubahan rute perintis menjadi rute komersial; atau

3. penghapusan rute perintis

Penetapan sebagai rute perintis pada tahun berikutnya harus memenuhi ketentuan sebagai berikut :

1. fungsi keperintisan, yaitu :

a. belum tersedia moda transportasi lain dengan kapasitas yang cukup dan waktu pelayanan yang teratur atau tersedia moda transportasi lain selain angkutan udara dengan kapasitas relatif kecil dan waktu pelayanan tidak teratur;

b. pertumbuhan ekonomi dan peningkatan taraf hidup masyarakatan dan pemerintahan dengan daerah atau wilayah lain; dan / atau

c. meningkatnya hubungan sosial, budaya, kemasyarakatan dan pemerintahan dengandaerah atau wilayah lain; dan/atau

d. daerah tersebut berdekatan dengan perbatasan negara lain.

2. kinerja penyelenggaraan angkutan udara perintis, meliputi :

a. tercapainya target frekuensi penerbangan yang ditetapkan;

b. tercapainya target penumpang yang diangkut yang ditetapkan; dan/atau

c. tercapainya target barang yang diangkut yang ditetapkan, khusus untuk subsidi angkutan barang.

Perubahan rute perintis menjadi rute komersial dilakukan setelah memenuhi ketentuan sebagai berikut:

1. kebutuhan jasa angkutan udara meningkat dengan ada loadfactor diatas $70 \%$ dan frekuensi lebih dari 4 (empat) kali per minggu.

2. kemampuan daya beli masyarakat tinggi

3. tarif perintis telah sesuai dengan tarif angkutan udara niaga berjadwal; dan/atau

4. terdapat badan usaha angkutan udara niaga berjadwal yang bersedia untuk melayani rute tersebut secara komersial dan berkesinambungan.

Penghapusan rute perintis dilakukan setelah memenuhi ketentuan sebagai berikut :

1. Tidak memenuhi fungsi keperintisan

a. rute tersebut sudah tersedia moda transportasi lain dengan kapasitas yang cukup dan waktu pelayanan yang teratur;

b. rute tersebut sudah dilayani angkutan udara komersial secara penuh;

c. pelayanan angkutan udara perintis tidak mendorong pertumbuhan kegiatan perekonomian antar daerah atau wilayah;

d. pelayanan angkutan udara perintis tidak meningkatkan hubungan sosial, budaya, kemasyarakatan dan pemerintahan dengan daerah atau wilayah lain.

2. Tidak memenuhi kinerja penyelenggaraan angkutan udara perintis 
a. tidak ada pertumbuhan penumpang dan barang diangkut serta target jumlah penumpang minimal tidak tercapai;

b. penggunaan tipe pesawat yang kurang cocok dengan kondisi bandar udara;

c. tidak ada badan usaha angkutan udara niaga berjadwal yang bersedia melayani rute perintis yang telah ditetapkan;

d. bandar udara yang digunakan untuk kegiatan operasi angkutan udara tidak memenuhi persyaratan keselamatan dan keamanan penerbangan

\section{Alat Analisis}

Analisis SWOT merupakan suatu teknik perencanaan strategi yang bermanfaat untuk mengevaluasi kekuatan (strength) dan kelemahan (weakness), peluang (opportunities), dan ancaman (threats) dalam suatu organisasi/perusahaan, baik yang sedang berlangsung maupun dalam perencanaan baru.

Penilaian SWOT ini membantu untuk menetapkan prioritas mana saja yang harus didahulukan oleh organisasi/perusahaan, apakah hal itu berasal dari internal ataukah dari faktor eksternal organisasi/perusahaan. Tujuannya adalah untuk menemukan aspek-aspek penting dari kekuatan, kelemahan, peluang, dan ancaman di dalam suatu perusahaan atau organisasi. Dengan empat aspek tersebut, diharapkan mampu memaksimalkan kekuatan, meminimalkan kelemahan, mengurangi ancaman, dan membangun peluang-peluang di masa depan.

Langkah-langkah dalam membuat analisis SWOT adalah :

1. menetapkan konteks yang akan dianalisis, agar tidak melebar. Sebaiknya konteks fokus pada tujuan yang ingin dicapai (goal);

2. menggunakan metodologi dalam membuat analisis SWOT. Konsep SWOT dibangun berdasarkan empat komponen mendasar, yaitu kekuatan (strength) dan kelemahan (weakness), peluang (opportunities), dan ancaman (threats) dengan kriteria sebagai berikut :

a. Kekuatan (strength) dan peluang (opportunities) adalah semua hal yang mendukung dalam mencapai tujuan yang ingin dicapai, sementara kelemahan (weakness) dan ancaman (threats) adalah segala sesuatu yang menghambat dalam mencapai tujuan yang ingin dicapai;

b. Kekuatan (strength) dan kelemahan (weakness) merupakan faktor-faktor analisis yang sumbernya berasal dari internal, sedangkan peluang (opportunities) dan ancaman (threats) merupakan faktor-faktor analisis yang sumbernya berasal dari eksternal;

3. mengidentifikasi dan menginventarisir apa saja yang menjadi : kekuatan (strength) dan kelemahan (weakness), peluang (opportunities), dan ancaman (threats).

\section{METODE PENELITIAN}

Metode penelitian yang digunakan adalah metode penelitian deskriftif yang tujuannya untuk menyajikan gambaran lengkap mengenai setting sosial atau dimaksudkan untuk mengeksplorasi dan mengklarifikasi mengenai suatu fenomena atau kenyataan sosial.

Objek penelitian adalah Kantor UPBU Inanwatan dengan melakukan observasi serta inventarisasi (brainstorming) faktor-faktor dari empat komponen mendasar, yaitu kekuatan (strength) dan kelemahan (weakness), peluang (opportunities), dan ancaman (threats) berdasarkan kejadian-kejadian yang faktual di lapangan.

\section{HASIL DAN PEMBAHASAN}

Tujuan yang ingin dicapai dalam membuat analisis SWOT ini adalah berupa strategi pengembangan Bandar Udara Inanwatan yang memenuhi standar keamanan dan keselamatan penerbangan dan memberi dampak pertumbuhan ekonomi bagi masyarakat Inanwatan. 
Dua tujuan tersebut di atas merupakan hal-hal yang tidak dapat dipisahkan. Kantor UPBU Inanwatan berkewajiban mewujudkan standar-standar keamanan dan keselamatan penerbangan untuk terpenuhi di Bandar Udara Inanwatan. Di samping itu juga tidak terlepas dari tujuan diadakannya angkutan udara perintis ke Inanwatan yaitu :

1. untuk menghubungkan daerah terpencil dan daerah tertinggal atau daerah yang belum terlayani oleh moda transportasi lain, dan secara komersial belum menguntungkan; dan/atau

2. untuk mendorong pertumbuhan dan pengembangan wilayah; dan/atau

3. untuk mewujudkan stabilitas pertahanan dan keamanan negara.

Indikator pertumbuhan ekonomi di Inanwatan secara sederhana kasat mata dapat dilihat dari besar kecil pendapatan masyarakat, tingkat perputaran uang dan pertumbuhan modal yang juga berpengaruh pada tingkat permintaan pembelian tiket pesawat dari dan menuju Inanwatan.

\section{Analisis SWOT}

Sebelum melakukan analisis SWOT, terlebih dahulu melakukan identifikasi dan inventarisir apa saja yang menjadi kekuatan (strength) dan kelemahan (weakness), peluang (opportunities), dan ancaman (threats). Daftar hasil inventarisir tersebut diklasifikasikan dalam faktor-faktor yang mendukung atau menghambat dalam mencapai tujuan yang ingin dicapai, diklasifikasikan dalam faktor internal atau faktor eksrternal.

Prosedur analisis faktor-faktor internal (IFAS = Internal Factor Analysis Summary) adalah sebagai berikut :

1. menyusun faktor-faktor yang menjadi kekuatan dan kelemahan;

2. memberikan bobot masing-masing faktor strategis dengan skala 1,0 (sangat penting) sampai dengan 0,0 (tidak penting). Penjumlahan semua bobot tersebut adalah $=1,00$;

3. melakukan pemberian rating skala 5-1 untuk kekuatan (kekuatan yang besar diberikan nilai 5 dan yang paling kecil diberikan nilai 1 );

4. melakukan pemberian rating skala 1-5 untuk kelemahan (kelemahan yang besar di berikan nilai 1 dan yang paling kecil diberikan nilai 5);

5. melakukan perkalian antar bobot dengan rating sehingga diperoleh nilai untuk setiap faktor;

6. nilai setiap faktor di jumlahkan sehingga diperoleh nilai total untuk faktor strategi internal. Nilai ini menunjukkan bagaimana organisasi/perusahaan bereaksi terhadap faktor-faktor internalnya.

Prosedur analisis faktor-faktor eksternal (EFAS = External Factor Analysis Summary) adalah sebagai berikut :

1. menyusun faktor-faktor yang menjadi peluang dan ancaman;

2. memberikan bobot masing-masing faktor strategis dengan skala 1,0 (sangat penting) sampai dengan 0,0 (tidak penting). Penjumlahan semua bobot tersebut adalah $=1,00$;

3. melakukan pemberian rating skala 5-1 untuk peluang (peluang yang besar diberikan nilai 5 dan yang paling kecil diberikan nilai 1 );

4. melakukan pemberian rating skala 1-5 untuk ancaman (ancaman yang besar di berikan nilai 1 dan yang paling kecil diberikan nilai 5);

5. melakukan perkalian antar bobot dengan rating sehingga diperoleh nilai untuk setiap faktor;

6. nilai setiap faktor di jumlahkan sehingga diperoleh nilai total untuk faktor strategi eksternal. Nilai ini menunjukkan bagaimana organisasi/perusahaan bereaksi terhadap faktor-faktor eksternalnya.

Setelah melakukan brainstorming, maka diperoleh daftar sebagai berikut :

1. faktor internal :

a. kekuatan (strength) : 
1) Bandar udara milik Kementerian Perhubungan;

2) peraturan yang berlaku di bidang Penerbangan, baik internasional seperti ANNEX dan suplemennya dan juga Undang-undang Nomor 1 tentang Penerbangan berikut peraturan-peraturan turunannya;

3) ketersediaan anggaran setiap tahun;

4) tugas pokok dan fungsi setiap personel dipetakan dengan jelas;

5) ketersediaan lahan untuk pengembangan Bandara Inanwatan seluas $418.833 \mathrm{~m} 2$.

b. kelemahan (weakness) :

1) keterbatasan SDM, memiliki 10 orang PNS dan 21 orang outsourcing, sebesar $71,43 \%$ dari outsourcing tersebut diambil dari suku asli di Papua Barat;

2) anggaran pengembangan bandar udara relatif terbatas;

3) lokasi bandar udara terpencil.

4) area sisi udara belum sepenuhnya dipagar;

5) kondisi runway strip dengan dimensi belum memenuhi ketentuan.

2. faktor eksternal :

a. peluang (opportunities) :

1) transportasi udara merupakan pilihan utama;

2) harga tiket pesawat subsidi pemerintah;

3) peran Pemerintah Kabupaten Sorong Selatan dan Provinsi Papua Barat;

4) potensi hasil laut berupa udang dan lobster bambu.

b. ancaman (threats) :

1) sengketa masalah tanah ulayat Inanwatan;

2) pendapatan perkapita masyarakat Inanwatan relatif rendah;

3) terdapat obstacle pada kawasan ancangan pendaratan dan lepas landas (approach);

4) kebijakan Pemerintah terkait Pencabutan Penerimaan Pegawai lewat jalur PPNPN.

Adapun perhitungan bobot dan rating faktor-faktor internal dan eksternal ditampilkan dalam tabel berikut ini :

\section{Tabel 2. Matriks IFAS}

\begin{tabular}{|l|c|c|c|}
\hline Faktor-faktor Internal : & Bobot & Rating & Skor \\
\hline Kekuatan: & & & \\
1. Bandar udara milik Kementerian Perhubungan; & 0,11 & 5 & 0,56 \\
2. peraturan yang berlaku di bidang Penerbangan, baik & 0,11 & 5 & 0,56 \\
internasional seperti ANNEX dan suplemennya dan juga & & & \\
Undang-undang Nomor 1 tentang Penerbangan berikut & & & \\
peraturan-peraturan turunannya; & 0,11 & 5 & 0,56 \\
3. ketersediaan anggaran setiap tahun; & 0,11 & 5 & 0,56 \\
4. tugas pokok dan fungsi setiap personel dipetakan dengan jelas; & 0,11 & 5 & 0,56 \\
5. ketersediaan lahan untuk pengembangan Bandara Inanwatan & & & \\
seluas 418.833 m2. & & & \\
\hline $\begin{array}{l}\text { Kelemahan : } \\
\text { 1. keterbatasan SDM, memiliki 10 orang PNS dan 21 orang } \\
\text { outsourcing, sebesar 71,43\% dari } \text { outsourcing tersebut diambil } \\
\text { dari suku asli di Papua Barat; }\end{array}$ & & & \\
2. anggaran pengembangan bandar udara relatif terbatas; & 0,07 & & \\
3. lokasi bandar udara terpencil. & 3 & 0,18 \\
4. area sisi udara belum sepenuhnya dipagar; & 0,07 & 3 & 0,20 \\
\end{tabular}




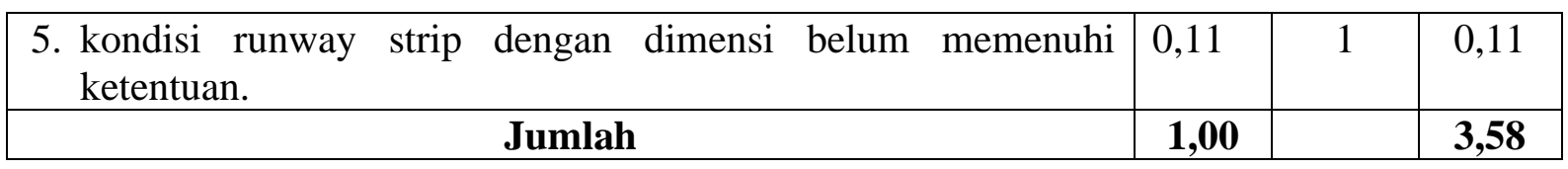

Tabel 3. Matriks EFAS

\begin{tabular}{|c|c|c|c|}
\hline Faktor-faktor Eksternal : & Bobot & Rating & Skor \\
\hline Peluang : & & & \\
\hline 1. transportasi udara merupakan pilihan utama; & 0,13 & 4 & 0,57 \\
\hline 2. harga tiket pesawat subsidi pemerintah; & 0,13 & 4 & 0,57 \\
\hline $\begin{array}{l}\text { 3. peran Pemerintah Kabupaten Sorong Selatan dan Provinsi } \\
\text { Papua Barat; }\end{array}$ & 0,10 & 3 & 0,29 \\
\hline 4. potensi hasil laut berupa udang dan lobster bambu. & 0,10 & 3 & 0,29 \\
\hline Ancaman : & & & \\
\hline 1. sengketa masalah tanah ulayat Inanwatan; & 0,13 & 2 & 0,26 \\
\hline 2. pendapatan perkapita masyarakat Inanwatan relatif rendah; & 0,13 & 2 & 0,26 \\
\hline $\begin{array}{l}\text { 3. terdapat obstacle pada kawasan ancangan pendaratan dan lepas } \\
\text { landas (approach); }\end{array}$ & 0,16 & 1 & 0,16 \\
\hline $\begin{array}{l}\text { 4. kebijakan Pemerintah terkait Pencabutan Penerimaan Pegawai } \\
\text { lewat jalur PPNPN. }\end{array}$ & 0,13 & 2 & 0,26 \\
\hline Jumlah & 1,00 & & 2,55 \\
\hline
\end{tabular}

\section{Strategi Pengembangan}

Dengan daftar yang ada, maka dapat dibuat strategi pengembangan dengan langkahlangkah sebagai berikut :

1. Bagaimana cara kekuatan (strengths) bisa mengambil keuntungan (advantage) dari peluang (opportunities) yang ada saat ini;

2. Bagaimana cara mengatasi kelemahan (weakness) yang menghambat kita dalam mengambil keuntungan (advantage) dari peluang (opportunities) yang ada;

3. Bagaimana kekuatan (strengths) mampu menghadapi berbagai hambatan atau ancaman (threats) yang ada.

4. Bagaimana cara mengatasi kelemahan (weakness) yang mampu menghadapi berbagai hambatan atau ancaman (threats) yang ada.

Dari langkah-langkah tersebut di atas, dapat disusun strategi pengembangan Bandar Udara Inanwatan yang memenuhi standar keamanan dan keselamatan penerbangan dan memberi dampak pertumbuhan ekonomi bagi masyarakat Inanwatan.

Strategi-strategi tersebut adalah sebagai berikut :

1. Strategi SO (Strength-Opportunity) :

a. peningkatan kapasitas pelayanan kepada pengguna jasa transportasi udara di Bandar Udara Inanwatan;

b. penyusunan rencana dan program pengembangan Bandar Udara Inanwatan dan peningkatan fasilitas keamanan dan keselamatan penerbangan, diusulkan melalui sumber dana APBN dan/atau peran serta Pemerintah Kabupaten Sorong Selatan dan Provinsi Papua Barat melalui APBD;

c. mendorong Koperasi Bandar Udara Inanwatan untuk bekerja sama dengan UMKM / masyarakat Distrik Inanwatan dalam budi daya udang dan lobster bambu.

2. Strategi WO (Weakness-Opportunity) :

a. mengusulkan program pendidikan dan latihan bagi pegawai Bandar Udara Inanwatan sehingga mendapatkan lisensi sesuai tugas pokok dan fungsinya; 
b. membina pegawai PPNPN dari masyarakat Inanwatan dan memberikan pelatihan kepada mereka.

3. Strategi ST (Strength-Threat) :

a. melaksanakan program padat karya yang melibatkan masyarakat Inanwatan;

b. berkoordinasi dengan Pemerintah Kabupaten Sorong Selatan untuk membongkar tiang antenna dan relokasi bangunan sekolah yang menjadi obstacle;

c. berkoordinasi dengan Direktorat Jenderal Perhubungan Udara untuk mencari solusi terkait peraturan tersebut, khususnya bagi Provinsi Papua dan Papua Barat.

4. Strategi WT (Weakness - Threat) :

a. peningkatan partisipasi masyarakat dalam turut menjaga keamanan dan keselamatan penerbangan di Bandara Inanwatan;

b. Bekerja sama dengan aparat Kepolisian dan TNI dalam menjaga keamanan Bandara Inanwatan;

c. Menerapkan program pengelolaan keselamatan penerbangan.

Tabel 4. Matriks SWOT strategi pengembangan Bandar Udara Inanwatan

\begin{tabular}{|c|c|c|}
\hline Eksternal & $\begin{array}{l}\text { Peluang (opportunities) : } \\
\text { 1. transportasi udara } \\
\text { merupakan pilihan utama; } \\
\text { 2. harga tiket pesawat } \\
\text { subsidi pemerintah; } \\
\text { 3. peran Pemerintah } \\
\text { Kabupaten Sorong Selatan } \\
\text { dan Provinsi Papua Barat; } \\
\text { 4. potensi hasil laut berupa } \\
\text { udang dan lobster bambu. }\end{array}$ & 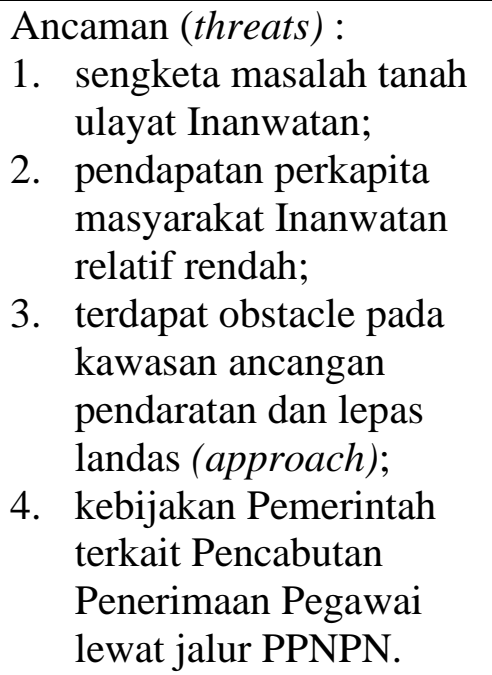 \\
\hline Internal & & \\
\hline $\begin{array}{l}\text { Kekuatan (strength) : } \\
\text { 1. Bandar udara milik } \\
\text { Kementerian } \\
\text { Perhubungan; } \\
\text { 2. peraturan yang berlaku di } \\
\text { bidang Penerbangan, baik } \\
\text { internasional seperti } \\
\text { ANNEX dan } \\
\text { suplemennya dan juga } \\
\text { Undang-undang Nomor } 1 \\
\text { tentang Penerbangan } \\
\text { berikut peraturan- } \\
\text { peraturan turunannya; } \\
\text { 3. ketersediaan anggaran } \\
\text { setiap tahun; } \\
\text { 4. tugas pokok dan fungsi } \\
\text { setiap personel dipetakan } \\
\text { dengan jelas; }\end{array}$ & $\begin{array}{l}\text { Strategi SO : } \\
\text { 1. peningkatan kapasitas } \\
\text { pelayanan kepada } \\
\text { pengguna jasa } \\
\text { transportasi udara di } \\
\text { Bandar Udara Inanwatan; } \\
\text { 2. penyusunan rencana dan } \\
\text { program pengembangan } \\
\text { Bandar Udara Inanwatan } \\
\text { dan peningkatan fasilitas } \\
\text { keamanan dan } \\
\text { keselamatan } \\
\text { penerbangan, diusulkan } \\
\text { melalui sumber dana } \\
\text { APBN dan/atau peran } \\
\text { serta Pemerintah } \\
\text { Kabupaten Sorong } \\
\text { Selatan dan Provinsi } \\
\end{array}$ & $\begin{array}{l}\text { Strategi ST: } \\
\text { 1. } \text { melaksanakan program } \\
\text { padat karya yang } \\
\text { melibatkan masyarakat } \\
\text { Inanwatan; } \\
\text { 2. } \text { berkoordinasi dengan } \\
\text { Pemerintah Kabupaten } \\
\text { Sorong Selatan untuk } \\
\text { membongkar tiang } \\
\text { antenna dan relokasi } \\
\text { bangunan sekolah yang } \\
\text { menjadi obstacle; } \\
\text { 3. berkoordinasi dengan } \\
\text { Direktorat Jenderal } \\
\text { Perhubungan Udara } \\
\text { untuk mencari solusi } \\
\text { terkait peraturan } \\
\text { tersebut, khususnya bagi }\end{array}$ \\
\hline
\end{tabular}




\begin{tabular}{|c|c|c|}
\hline $\begin{array}{l}\text { 5. ketersediaan lahan untuk } \\
\text { pengembangan Bandara } \\
\text { Inanwatan seluas } 418.833 \\
\text { m2. }\end{array}$ & $\begin{array}{l}\text { Papua Barat melalui } \\
\text { APBD; } \\
\text { 3. mendorong Koperasi } \\
\text { Bandar Udara Inanwatan } \\
\text { untuk bekerja sama } \\
\text { dengan UMKM / } \\
\text { masyarakat Distrik } \\
\text { Inanwatan dalam budi } \\
\text { daya udang dan lobster } \\
\text { bambu. }\end{array}$ & $\begin{array}{l}\text { Provinsi Papua dan } \\
\text { Papua Barat. }\end{array}$ \\
\hline $\begin{array}{l}\text { Kelemahan (weakness) : } \\
\text { 1. keterbatasan SDM, } \\
\text { memiliki } 10 \text { orang PNS } \\
\text { dan } 21 \text { orang } \\
\text { outsourcing, sebesar } \\
\text { 71,43\% dari outsourcing } \\
\text { tersebut diambil dari } \\
\text { suku asli di Papua Barat; } \\
\text { 2. anggaran pengembangan } \\
\text { bandar udara relatif } \\
\text { terbatas; } \\
\text { 3. lokasi bandar udara } \\
\text { terpencil. } \\
\text { 4. area sisi udara belum } \\
\text { sepenuhnya dipagar; } \\
\text { 5. kondisi runway strip } \\
\text { dengan dimensi belum } \\
\text { memenuhi ketentuan. }\end{array}$ & $\begin{array}{l}\text { Strategi WO : } \\
\text { 1. mengusulkan program } \\
\text { pendidikan dan latihan } \\
\text { bagi pegawai Bandar } \\
\text { Udara Inanwatan } \\
\text { sehingga mendapatkan } \\
\text { lisensi sesuai tugas pokok } \\
\text { dan fungsinya; } \\
\text { 2. membina pegawai } \\
\text { PPNPN dari masyarakat } \\
\text { Inanwatan dan } \\
\text { memberikan pelatihan } \\
\text { kepada mereka. }\end{array}$ & $\begin{array}{l}\text { Strategi WT: } \\
\text { 1. } \text { peningkatan partisipasi } \\
\text { masyarakat dalam turut } \\
\text { menjaga keamanan dan } \\
\text { keselamatan } \\
\text { penerbangan di Bandara } \\
\text { Inanwatan; } \\
\text { 2. Bekerja sama dengan } \\
\text { aparat Kepolisian dan } \\
\text { TNI dalam menjaga } \\
\text { keamanan Bandara } \\
\text { Inanwatan; } \\
\text { 3. Menerapkan program } \\
\text { pengelolaan keselamatan } \\
\text { penerbangan. }\end{array}$ \\
\hline
\end{tabular}

\section{KESIMPULAN}

Berdasarkan hasil analisis dan pembahasan atas masalah yang telah dikemukakan sebelumnya, maka penulis dapat menarik beberapa kesimpulan dari hasil analisis yaitu sebagai berikut :

1. Berdasarkan faktor internal dan eksternal yang menunjukkan matriks IFAS (Internal factor Analysis Summary) diperoleh nilai 3,58 dan EFAS (External Factor Analysis Summary) diperoleh nilai 2,55.

2. Hasil analisis matriks IFAS dengan nilai di atas 2,5 berarti bahwa Kantor UPBU Inanwatan menunjukkan ciri organisasi yang kuat secara internal yang artinya strategi organisasi dapat memanfaatkan faktor kekuatan yang ada dan juga mampu meminimalkan kelemahan berada di atas rata-rata.

3. Hasil analisis matriks EFAS dengan nilai di atas 2,5 menunjukkan bahwa Kantor UPBU Inanwatan diyakini memiliki kemampuan memanfaakan peluang yang ada dari ancaman yang dihadapinya dalam menjalankan kegiatan organisasi.

4. Strategi pengembangan Bandar Udara Inanwatan ini dilakukan secara simultan, melalui pembagian tugas sesuai tugas pokok dan fungsi yang ada di Kantor UPBU Inanwatan dengan melibatkan para pihak yang terkait, utamanya masyarakat Inanwatan. 


\section{DAFTAR RUJUKAN}

Badan Pusat Statistik Kabupaten Sorong Selatan. 2019. Inanwatan Dalam Angka 2019. Sep, 2019. https://sorongselatankab.bps.go.id

Republik Indonesia. 2009. Undang-undang Nomor 1 Tahun 2009 tentang Penerbangan. Lembaran Negara Republik Indonesia Tahun 2009, Nomor 1. Sekretariat Negara RI. Jakarta.

Kementerian Perhubungan. 2016. Peraturan Menteri Perhubungan Republik Indonesia nomor PM 9 Tahun 2016 tentang Kriteria dan Penyelenggaraan Kegiatan Angkutan Udara Perintis. Berita Negara Republik Indonesia Tahun 2016, Nomor 65. Kementerian Hukum dan Hak Asasi Manusia RI. Jakarta.

Kementerian Perhubungan. 2019. Peraturan Menteri Perhubungan Republik Indonesia nomor PM 39 Tahun 2019 tentang Tatanan Kebandarudaraan Nasional. Berita Negara Republik Indonesia Tahun 2019, Nomor 594. Kementerian Hukum dan Hak Asasi Manusia RI. Jakarta.

Kementerian Perhubungan, Direktorat Jenderal Perhubungan Udara. 2019. Peraturan Direktur Jenderal Perhubungan Udara Nomor 326 Tahun 2019 tentang Standar Teknis dan Operasional Peraturan Keselamatan Penerbangan Sipil - Bagian 139 (Manual Of Standard Cask - Part 139) Volume I Bandar Udara (Aerodrome). Bagian Hukum Direktorat Jenderal Perhubungan Udara. Jakarta.

Kementerian Perhubungan, Direktorat Jenderal Perhubungan Udara. http://hubud.dephub.go.id/website/Bandara.php

Fadjar Nugroho (2008). Visual Flight Rules. April 11, 2008. Ilmu Terbang.com. http://www.ilmuterbang.com/artikel-mainmenu-29/teori-penerbangan-mainmenu-68/65visual-flight-rules

Tom MC Ifle (2019). TIPS MANAJEMEN! 4 Cara Melakukan SWOT Analisis. Feb 13, 2001. https://youtu.be/q1pEfRefRJA

Emron Bandung (2019). Analisis SWOT Perhitungan Bobot \& Rating. Jun 19, 2019. https://youtu.be/f2PugGuznN4

Brata Taruna Hardjo Subroto (2019). Menyusun Strategi Perusahaan dengan Menggunakan Analisa SWOT. Sep 24, 2019. https://youtu.be/xkJMGsCsvDw

Fakhri Zahir (2020). Cara Membuat Analisis SWOT (step-by-step). March 7, 2001. https://alphapay.id/cara-membuat-analisis-swot-step-by-step/

Bivisyani Questibrilia (2019). Cara Membuat Analisis SWOT Untuk Perusahaan Startup. Jul 19, 2019.

JOJONOMIC. https://jojonomic.com/blog/analisis-swot/ 